\title{
Local and counter-memories of socialism in post-socialist Romania
}

\author{
Duncan Light and Craig Young \\ In: Beyen, M. and Deseure, B. (eds) Local Memories in a Nationalizing and Globalizing \\ World, Palgrave, Basingstoke, 2015, pp 221-243
}

\section{INTRODUCTION}

Any radical political change produces a dramatic reformulation of national history and public memory among both elites and publics and at a variety of scales. The post-socialist states of East-Central Europe (ECE) represent one of the best contemporary examples. In the two decades since overthrowing authoritarian socialist regimes, the countries of this region have struggled with their recent past. Debates around history and memory in the post-socialist period have predominantly focused on World War II, the Holocaust and various inter-War periods of independence. However, at the heart of this issue, and the focus of this chapter, is the tension between remembering and forgetting the socialist era. At the 'official' level - the arena of national politics - there is generally little interest in remembering socialism. In some countries there is the possibility of officially recognizing anti-Communist resistance (such as Solidarity in Poland) or the victims of Communism, and in some cases there is recognition of the importance of some Communist figures for the nation (for example, the reburial of Imry Nagy in Hungary in 1989). However, the dominant imperative to demonstrate allegiance to global political and economic orthodoxies (and make a claim for membership of transnational organisations such as NATO or the EU) requires an emphatic repudiation of socialist rule. However, at a more local scale, individual memories of the socialist era cannot be simply erased or denied. Instead, within their everyday lives many people may remember socialism in a more ambivalent and nuanced manner. Such local memories can constitute a form of 'counter-memory" ${ }^{\prime}$ : practices of remembrance that are out of alignment with the efforts of the state to shape and define the remembrance of the socialist era. Such local counter-memories of socialism are discordant with the 'official' imperatives to repudiate socialism.

In this chapter we examine such local memories of socialism in post-socialist Romania. To establish a context for the later discussion we start by considering the nature of official and popular memory under state socialism. We then consider the fluid and dynamic nature of memory in post-socialist societies focusing on two, seemingly contradictory trends: the 'official' rejection of the socialist era, and popular nostalgia for, and remembrance of, that same past. We go on to explore this tension between remembering and forgetting with reference to locally-grounded memories of major socialistera Romanian politicians. Such figures are condemned at the level of official discourse for their involvement in the socialist regime, but such disapprobation is contested at the local level where they are remembered in far more approving terms.

\section{ANTECEDENTS: OFFICIAL AND LOCAL MEMORY UNDER SOCIALISM}

To understand the nature of local memory and counter-memory under post-socialism it is necessary to consider the historical context of memory formation in state socialist regimes. Communist Party regimes came to power throughout East-Central Europe after the Second World War intent on a radical transformation of society and the creation of a 'new world'. The founding principle of

\footnotetext{
${ }^{1}$ S.Legg, 'Reviewing geographies of memory/forgetting', Environment and Planning A, 39/2 (2007), pp 456466.

${ }^{2}$ L.Boia, Mitologia Ştiințifică a Comunismului, (Bucureşti: Humanitas, 1999) pp. 39-40.
} 
socialist regimes was a decisive break with the past, so that almost everything inherited from the presocialist order needed to be dismantled. Political pluralism was abolished to be replaced by uncontested rule by the Communist Party. Capitalist economies were replaced by nationalized ownership of the means of production, followed in turn by centralised economic planning intended to eliminate the social and spatial inequalities created by capitalism. The social structures of the former regime - education, religion, the judicial system - were all remade in accordance with the agenda of state socialism.

In this context socialist Party-states also sought to transform senses of individual and collective identities in order to create a "new socialist man". ${ }^{3}$ Initially this involved attempting to eliminate senses of national identity - since the nation was conceived as a specifically bourgeois concept - and replace them with a new sense of class solidarity and socialist internationalism. In order to remake identities it was necessary to remake the past in order to reshape collective memory (particularly since memories of the pre-socialist era were an implicit threat to the new regime $\left.{ }^{4}\right)$. Thus Communist Party regimes swiftly set about rewriting history to legitimate their rule. The Party-state was in a position to do this since it enjoyed a monopoly over the production of history ${ }^{5}$ through its appointment of academic historians and control of the educational system. Revising the past took a number of familiar, Orwellian forms. Formerly central events and personalities (such as monarchs or liberal politicians) were erased from the historical narrative, while the statues that had commemorated them were removed and the streets that honoured them were renamed. At the same time, new figures who exemplified class struggle were elevated to hero status, while the events in which they had participated were celebrated and commemorated. In some cases, historical revisionism was intended to eliminate historical senses of identification with Western Europe, since the West was now the ideological enemy. For example, in Romania, the socialist rewriting of history involved downplaying cultural ties with Western Europe (particularly France), whilst asserting (or inventing) long-standing historical ties with Russia. ${ }^{6}$

However, while socialist regimes sought to falsify and obliterate memory ${ }^{7}$ in their efforts to transform historical consciousness they were only partially successful. Communist party-states were much less powerful than is often supposed ${ }^{8}$ and did not enjoy absolute. Thus, the attempts by Party-states to shape individual memories were refracted through a range of other experiences including personal, family and community memories. ${ }^{9}$ Thus socialist regimes were unable to prevent the circulation of alternative and local visions of the past, present and future ${ }^{10}$ that diverged from the 'official' line. They included memories of events and personalities from the pre-socialist period that remained alive within popular memory. Similarly, despite attempts to discourage religious observance, memories of religious practices and traditions persisted stubbornly at the local level. Efforts to create collective farms failed to erase local memories of private property boundaries. ${ }^{11}$ Indeed, sometimes such local, counter-memories were circulated as a deliberate act of resistance to state power.

\footnotetext{
${ }^{3}$ Ibid, p. 122.

${ }^{4}$ G.Kligman and K. Verdery, Peasants under Siege: The Collectivization of Romanian Agriculture, 1949-1962

(Princeton: Princetown University Press, 2011),p. 17.

${ }^{5}$ M.Ciobanu, 'Rewriting and remembering Romanian communism: some controversial issues', Nationalities Papers, 39/2 (2011), 205-221.

${ }^{6}$ L.Boia, History and Myth in Romanian Consciousness (Budapest: Central European University Press, 2001), pp.70-73.

V. Tismaneanu 'Coming to terms with a traumatic past: Reflections on democracy, atonement, and memory', in History of Communism in Europe, Vol 1: Politics of Memory in Post-Communist Europe (Bucharest: Zeta Books, 2010), p.17.

${ }^{8}$ K.Verdery, National Ideology under Socialism: Identity and Cultural Politics in Ceauşescu's Romania (Berkeley: University of California Press, 1991), pp 83-87.

${ }^{9}$ Kligman and Verdery Peasants, p 13.

${ }^{10}$ S.Boym, The Future of Nostalgia (New York, Basic Books, 2001), pp 61-62.

${ }^{11}$ K. Verdery, What was Socialism and What Comes Next? (Princeton: Princeton University Press, 1996), p.157.
} 
In addition, socialist regimes were not entirely successful in their attempt to eradicate national identities. Indeed, as Verdery argues ${ }^{12}$, the national idea was so effectively inculcated in ECE that Community Party regimes were unable to expunge national sentiments. Thus, some socialist states came to accept national ideology and sometimes used it within powerful programmes intended to shape memory and national identity. ${ }^{13}$ For example, the Communist authorities in post-War Poland made considerable efforts to establish a sense of Polishness which involved a rewriting of history combined with the expulsion of other national and ethnic populations, cultures and memories within the newly established state boundaries. ${ }^{14}$

\section{MEMORY IN POST-SOCIALIST SOCIETIES}

The socialist states of ECE collapsed between 1989 and 1991 while the Soviet Union was dissolved at the end of 1991. All these countries (to varying degrees) renounced single-party rule and centralized economic planning, and committed themselves to radical political and economic reform. As they exited from socialist rule, post-socialist societies faced a dilemma similar to that experienced by other countries at the end of a period of authoritarian rule: how is society to come to terms with a problematic and traumatic past founded on values that are now rejected, and which represents the very antithesis of the country's future aspirations. In post-socialist societies the recent past has become highly politicized and a range of actors (both elites and publics ${ }^{15}$ ) have participated (and often competed) in efforts to shape the ways in which society approaches and negotiates its relationship with the socialist era. All shifts in political power generate "a reconfiguration of the "known past"" 16 and in this context memory in post-socialist societies is fluid, dynamic, fractured and contested. Hence, it is hardly surprising that dealing with the socialist past has consumed considerable time and energy in post-socialist societies. ${ }^{17}$ Moreover, different countries have approached their socialist past in different ways. Some (such as the former East Germany and Czechoslovakia) have 'dealt' swiftly and decisively with their socialist past, while others (such as Romania, Bulgaria, the former Yugoslavia and Albania) have found the process more problematic. ${ }^{18}$ Nevertheless, throughout the formerly socialist states of ECE two broad trends can be identified: an emphatic rejection of the socialist past, and a more nebulous popular nostalgia for the recent past.

\section{The Rejection of the Socialist Past}

Throughout ECE and the Soviet Union the exit from socialism was marked by an immediate and public rejection of socialism. Socialist regimes had enjoyed little popular support or legitimacy in their final years among a populace eager for change. Consequently, beyond socialist diehards or those whose livelihood depended on the socialist system there were few voices calling for a retention of Communist Party rule. The opposition groups that, in many countries, had played a key role in bringing about the downfall of socialist regimes had based their platform on dismantling the political and economic structures of state socialism. The new model was the 'West' and most ECE countries regarded a rejection of socialism and a 'return to Europe' as different sides of the same coin. Having

\footnotetext{
12 Ibid p.85.

${ }^{13}$ D.Light and C. Young, 'Place, national identity and post-socialist transformations: an introduction', Political Geography, 20/8 (2001), pp. 941-55.

${ }^{14}$ M. Ziólkowski, 'Remembering and forgetting after Communism. The Polish case', Polish Sociological Review, 1 (2002), pp. 7-24.

${ }^{15}$ B.Forest, J.Johnson and K.Till, 'Post-totalitarian national identity: Public memory in Germany and Russia', Social and Cultural Geography, 5/3 (2004), pp. 357-380.

${ }^{16}$ Kligman and Verdery, Peasants, p. 9.

${ }^{17}$ H.A. Welsh, 'Dealing with the communist past: Central and Eastern European experiences after 1990', Europe-Asia Studies, 48/3 (1996), pp. 413-428.

${ }^{18}$ Gledhill, J. 'Integrating the past: Regional integration and historical reckoning in Central and Eastern Europe', Nationalities Papers, 39/4 (2011), pp. 481-506.
} 
long been 'Other' in political terms, post-socialist countries now sought to convince the West that they had definitively renounced socialism. Instead, post-socialist governments sought to establish new political identities as liberal 'European' states with which the West could do business. This entailed demonstrating their commitment to the transnational orthodoxies of multi-party democracy and neoliberal capitalism.

Within this political project, there was no place for the socialist past. Indeed, socialism represented the very antithesis of the political and economic values to which the East-Central European states aspired. In this context, socialism was treated as a huge aberration that was best forgotten: there was little to be learned from the socialist era and little to be gained from remembering it. Thus, in most post-socialist states, the socialist era was virtually erased from official memory, a strategy which Tismaneanu terms the "politics of forgetfulness" 19 . Such a situation is not, of itself, unique to the postsocialist world since it is well established that forgetting is as central to the formation of collective memory and national identities as remembrance and commemoration. ${ }^{20}$ It does, however, illustrate a distinctly post-socialist understanding of history in which a substantial part of the recent past can be simply erased from the national time line. Verdery ${ }^{21}$ argues that this practice "reveals an interesting conception of time, in which time is not fixed and irreversible. One can pick up the time line, snip and discard the communist piece of it that one no longer wishes to acknowledge, paste the severed ends together and hey presto! One has a new historical time line. One has not accepted and incorporated the recent past, one has simply excised it" In effect, post-socialism was about 'returning' to the historical trajectory of the pre-Second World War period, which had been disrupted by the Communist Party takeover. The four decades of socialism were - initially at least - treated as if they had not happened. Instead narratives of the past frequently focused on a variety of pre-socialist eras, especially those that could be reclaimed as a 'Golden Age' of the nation. ${ }^{22}$

This eradication of socialism from collective memory manifested itself in many ways. ${ }^{23}$ It involved the familiar and iconic processes of "landscape cleansing" 24 in which the public symbols of the socialist era were erased from public space. Thus, statues were torn down, streets renamed, and monumental socialist buildings given new uses appropriate to a post-socialist state. ${ }^{25}$ Museums closed their galleries which dealt with the recent past. Similarly, the socialist era disappeared from the school history curriculum. Other practices seek to reverse the events of the socialist period in an attempt to restore the situation the existed before socialism. Thus, property restitution seeks to restore property nationalized by the state to its former owners. Similarly, agricultural land that was forcibly absorbed into collective farms was returned to the original owners or their descendants.

This strategy of attempting to extirpate the socialist era from collective memory was not confined to political elites. Instead, it enjoyed widespread tacit support among much of the wider populace. Those who had harsh experiences of repression and suffering under totalitarian rule were reluctant to relive them. Others had dismal memories of austerity, shortages and harassment which they had little desire to remember. In addition, there were many who had an uneasy conscience and were unwilling to reflect on their own record of participation and complicity with the former regime. ${ }^{26}$ This was

\footnotetext{
${ }^{19}$ V. Tismaneanu, 'Democracy and memory: Romania confronts its Communist past', Annals of the American Academy of Political and Social Science, 617 (May 2008), pp. 166-180.

${ }^{20}$ D.Lowenthal, The Past is a Foreign Country (Cambridge, Cambridge University Press, 1985), p.204.

${ }^{21}$ K. Verdery, The Political Lives of Dead Bodies: Reburial and Post-Socialist Change (New York, Columbia University Press, 1999), p. 116.

${ }^{22}$ C. Young and S. Kaczmarek, 'The Socialist Past and Postsocialist Urban Identity in Central and Eastern Europe: The Case of Lodz, Poland', European Urban and Regional Studies, 15 (2008), pp. 53-70.

${ }^{23}$ For an overview see: L. Stan, 'Reckoning with the Communist Past in Romania: A scorecard', Europe-Asia Studies, 65/1 (2013), pp. 127-146.

${ }^{24}$ M. Czepczyński, Cultural Landscapes of Post-Socialist Cities: Representation of Powers and Needs, (Aldershot, Ashgate, 2010), p.109.

${ }^{25}$ B.Forest and J. Johnson, 'Monumental politics: Regime type and Public Memory in Post-Communist States', Post-Soviet Affairs, 27/3 (2011), pp. 269-288.

${ }^{26}$ Tismaneanu, Coming to terms, p. 15; Forest et al 'Post-totalitarian', p. 360.
} 
particularly the case in countries which had had an extensive internal security service (such as East Germany or Romania) where significant numbers of people were 'informants' of some kind. Rather than deal openly with such issues, most post-communist societies preferred to bury them: it was far easier to leave skeletons in the closet rather than disinter them and potentially face the resulting recrimination. While there have been many critics of this strategy it is entirely understandable as a personal response to dealing with a traumatic and unhappy past.

Over time, post-socialist societies developed a more ambivalent approach to their recent past. Efforts (among both elites and the wider public) to forget the socialist era had been challenged by many civil society groups and NGOS. Such bodies actively challenged the collective desire to forget by promoting remembrance of the socialist era, and particularly its atrocities and victims. In many cases, NGOS were active in the construction of memorials to the victims of totalitarian rule and often sought EU support for their activities. ${ }^{27}$ Such activities represented a form of counter-memory (and countermemorialisation) that challenged the dominant collective amnesia about the socialist past. Political pluralism and personal freedom has opened up space for a variety of evaluations of the socialist past to co-exist, especially in societies where decades of Communist rule have left a legacy of distrust of official narratives about the past. The marketization of the economy and the mediatisation of society has opened up new avenues for constructing memories of the socialist era, from television documentaries and webpages, new publishing houses producing a variety of memoirs and histories, and private tourism companies seeking to exploit interest in the socialist past.

Moreover, as the time interval between the present and the socialist era has increased, attitudes to that past started to change among both political elites and the wider public. While socialism was still repudiated in most countries, there was an increasing acknowledgment (although sometimes tentative) of the socialist era and its place in collective memory. There was increasing commemoration of the victims of the socialist era through the establishment of monuments, memorials and museums with a wide variety of sponsors. ${ }^{28}$ Gradually museum displays started to address the socialist era, while school history text books introduced a discussion of the socialist era (that had hitherto been entirely absent). Socialist-era archives were opened to researchers, including in some countries the records of surveillance undertaken by internal security services. In some cases there were formal reports or investigations into the socialist era (the best example being Romania's 'Presidential Commission for the Analysis of the Communist Dictatorship in Romania'). ${ }^{29}$

\section{Nostalgia for the Socialist Past}

The second defining characteristic of post-socialist memory is a paradoxical inversion of the desire to forget: nostalgia for the socialist era. Nostalgia can be defined as a "sentiment of loss and displacement". ${ }^{30}$ In this case, it takes the form of a wistful and sentimental remembrance (and sometimes a yearning for) the socialist era. In extreme forms it can involve an idealisation of the past and, in some cases, a desire to return to authoritarian Communist Party rule. More commonly it takes the form of a belief that not everything was bad under socialism ${ }^{31}$ and a longing for some of the certainties of the socialist era. Such nostalgia is an individual sentiment but is so widespread that it can be identified as a distinctive collective mood. The emergence of such post-socialist nostalgia was so unexpected that it shocked and surprised many in both Western Europe and the ECE countries

\footnotetext{
${ }^{27}$ Gledhill, 'Integrating', p. 501.

${ }^{28}$ Czepczyński, Cultural Landscapes, pp. 138-143; Forest and Johnson 'Monumental politics' pp. $276-281$.

${ }^{29}$ M. Ciobanu, 'Criminalising the past and reconstructing collective memory: The Romanian Truth

Commission', Europe-Asia Studies, 61/2 (2009),pp. 313-336.

${ }^{30}$ Boym, Future, p.xiii.

${ }^{31}$ J.Ekman and J. Linde, 'Communist Nostalgia and the Consolidation of Democracy in Central and Eastern Europe', Journal of Communist Studies and Transition Politics, 21/3 (2005), pp.354-374.
} 
themselves. ${ }^{32}$ Given the elation at the overthrow of socialist regimes few expected that, within a few years, many would be remembering that era with fondness.

The extent of post-socialist nostalgia is impossible to dismiss. As early as 1993 Eurobarometer surveys were indicating that significant minorities in all post-socialist countries (ranging from just over 5\% in the Czech Republic to more than $25 \%$ in Bulgaria) approved of a return towards Communist Party rule. ${ }^{33}$ Over time, the number of people reporting such sentiments has steadily increased and numerous studies have reported large minorities - and sometimes a majority - who feel that their lives were better under communism and that they would welcome a return to communist rule. Such nostalgia seems to be most pronounced among older people who lived and worked during the period of Communist Party rule and this group are also more likely to be sceptical towards democratic government. ${ }^{34}$ However, surprisingly, young people (who may sometimes have few direct memories of socialism) are also undogmatically appreciative of the former regime. ${ }^{35}$ The fact that nostalgia for socialism is so widespread among such a broad segment of society illustrates how the socialist era has become a firmly established part of collective memories in ECE, despite efforts to erase the socialist past from official memory.

Nostalgia for the socialist era takes many forms but is most apparent in popular culture. Since nostalgia is easily commodified ${ }^{36}$ numerous products have appeared that cater for the apparently enthusiastic remembrance of socialism. For example, recent films evoke the everyday conditions of life under socialist rule. Perhaps the best known is 'Good Bye Lenin' which tapped into a popular vein of what has been termed 'ostalgia' in the former East Germany. Similarly, in Romania 'Tales from the Golden Age' a collection of short films that played with various communist-era urban myths enjoyed considerable success. In 1998 the state television channel in the Czech Republic, rebroadcast 30 Cases of Major Zemen a television series from the 1970s about the work and home life of an ordinary police office. This was greeted by almost universal approval by Czechs of all ages. ${ }^{37}$ In Romania, a socialist-era brand of chocolate bar - 'Rom' - has been rebranded and relaunched and is reported to be now the most popular chocolate in the country. In Hungary a CD of patriotic socialist songs was a surprise hit in 1998, reaching number one in Hungary's music chart. ${ }^{38}$ And in Romania a businessman even opened a 'Museum of the Socialist Republic of Romania' offering an overtly nostalgic experience of Ceauşescu's Romania. ${ }^{39}$ In many other ways throughout ECE socialism 'sells' and products that overtly recall the socialist era find a ready market.

How, then, is this nostalgic remembrance of the socialist era to be explained? The answer lies in the profound upheaval that accompanied the dismantling of the socialist economy. The economic model adopted by almost all post-socialist states was that of Western neoliberal capitalism and while individual countries differed in the pace at which they sought to arrive at this goal the end point was the same. But while the populations of the socialist countries had been enthusiastic about political change they had often not anticipated the economic shock that post-socialism necessarily involved. Restructuring and privatisation of formerly state-owned industries resulted in huge job losses and rising unemployment, ending the socialist-era practice of a guaranteed job with a reasonable wage. The liberalisation of formerly state-controlled prices generated rapid inflation, and since wages rarely kept pace with rising prices most people experienced a decline in their living standards. The

\footnotetext{
${ }^{32}$ M.Velikonj, 'Lost in Transition: Nostalgia for Socialism in Post-socialist Countries', East European Politics and Societies, 23/4 (2009), pp.535-551.

${ }^{33}$ These figures are reported in Ekman and Linde 'Communist Nostalgia', p.359.

${ }^{34}$ Ekman and Linde, 'Communist Nostalgia', pp. 363-4.

${ }^{35}$ Velikonja, 'Lost' p.544; Ekman and Linde 'Communist Nostalgia', p.366.

${ }^{36}$ Velikonja 'Lost', pp.540-541.

${ }^{37}$ A. Roberts, 'The politics and anti-politics of nostalgia', East European Politics and Societies, 16/3 (200), pp.764-809.

${ }^{38}$ M.Nadkarni, "But it's ours": Nostalgia and the Politics of Authenticity in Post-Socialist Hungary', in M. Todorova and Z. Gille (ed.) Post-Communist Nostalgia, Berghahn, Oxford, pp.90-214.

${ }^{39}$ C. Preda, 'Looking at the Past through an Artistic Lens: Art of Memorialization', in History of Communism in Europe Vol 1 (2010), pp. 131-150.
} 
liberalisation of international trade meant a rapid inflow of imported Western goods and full exposure to cultural globalisation and Western consumer culture. ${ }^{40}$ Moreover, the elaborate social care system developed by socialist states was dismantled so that free health care and social security could no longer be guaranteed.

Along with the deteriorating material conditions of post-socialism, many people experienced a profound challenge to senses of personal identity. Post-socialist restructuring produced a severe "cultural shock' ${ }^{41}$ among large sectors of the population. A system that had seemed permanent and invincible had disappeared almost overnight. This sense of upheaval was superbly captured in the phrase "Everything was forever, until it was no more". ${ }^{42}$ Many people were profoundly unsettled to find that the system that had formed the entire context for their lives - within which they had lived and worked, and which had given their lives dignity and meaning ${ }^{43}$ - was now written off as a historical mistake. Some groups - such as the 'engineer class' created and exalted by socialism ${ }^{44}$ - found that their professional skills and training were now redundant in the new era of neoliberal capitalism. Many people who would never have described themselves as communists had taken pride in their work, and many more recognized that they were working within a system that sought to build a better and more equal world. They now discovered that everything they had worked for counted for nothing.

In these circumstances it is hardly surprising that many look back nostalgically to the socialist era. As Todorova $^{45}$ argues, this nostalgia comprises both a longing for something (order, stability, security, prosperity and a specific form of sociability and 'togetherness') and also a sense of loss for the certainties of socialism (jobs, houses, health care). However, such nostalgia is not a delusional form of escapism, neither is it a malady (as some critics have suggested). ${ }^{46}$ Instead, it is an individual and collective strategy for coming to terms with change. At times of shock or upheaval, it is a normal human reaction to search for solace and security, and this can frequently be found in the past. In this sense remembrance - and the activation of memory - is a purposeful strategy for coming to terms with change. Indeed, Boym identifies post-socialist nostalgia as a form of "defense mechanism". 47 Those who are nostalgic for socialism may miss those times but are not usually seeking to return to them. ${ }^{48}$ Instead, they are using memory as a way of dealing with the present. Moreover, this positive (and selective) way of thinking about the socialist era is transmitted from parents to children who, in turn, become curious about socialism and are not necessarily inclined to reject it out of hand.

In the context of state-sponsored projects to forget (or deny the legitimacy of) the socialist past, postsocialist nostalgia represents a significant form of counter-memory that keeps the memory of the socialist era alive. Counter-memory can be defined as a "refusal to remember in a conformist fashion" ${ }^{49}$ It embraces social rather than political history and ordinary rather than elite memories. ${ }^{50}$ It

\footnotetext{
${ }^{40}$ One of the authors has heard many times in Romania a lament along the lines of "Then [during the socialist era] we had money but there was nothing to buy. Now we can buy anything we want but we have no money to do so".

${ }^{41}$ Ekman and Linde, 'Communist nostalgia', p.371.

${ }^{42}$ A. Yurchak, Everything was Forever, Until it Was No More: The Last Soviet Generation, (Oxford, Princeton University Press, 2006).

${ }^{43}$ M.Todorova, 'From utopia to propaganda and back', in M. Todorova and Z. Gille (eds.) Post-Communist Nostalgia, (Oxford, Berghahn, 2010), pp.1-13.

${ }^{44}$ Boia, Mitologia, pp.133-4.

${ }^{45}$ Todorova, 'From utopia', p.7.

${ }^{46}$ Ibid p. 2.

${ }^{47}$ Boym, Future, p. 64.

${ }^{48}$ Velikonja, 'Lost', p.546.

${ }^{49}$ Legg, 'Reviewing', p.460.

${ }^{50}$ S.Legg, 'Contesting and surviving memory: space, nation and nostalgia in Les Lieux de Mémoire, Environment and Planning D, 23/4, (2005) pp 481-504; P.H. Hutton, History as an Art of Memory, (Hanover NH, University Press of New England, 1993).
} 
can also be explicitly associated with a refusal to forget. ${ }^{51}$ Nostalgia for socialism - which remembers the socialist era in positive terms, through the lens of the experiences of ordinary people - therefore directly confronts 'official' efforts to forget or reject the socialist past. Indeed, nostalgia for the socialist past can be a deliberate act of defiance: "a resistance strategy of preserving one's personal history and group's identity against the new ideological narratives, historical revisionism and imposed amnesia" ${ }^{52}$ As a form of counter-memory post-socialist nostalgia therefore problematizes the whole process of forgetting the socialist era. It also opens up the possibility of local memories of socialism that are discordant with state projects to reject the socialist era as a historical aberration. In the following section we explore such local, counter-memories in post-socialist Romania.

\section{LOCAL MEMORIES OF SOCIALISM IN POST-SOCIALIST ROMANIA}

\section{The National Context}

Romania exemplifies both trends discussed above: the repudiation of the socialist past and also nostalgia for that past. Under Nicolae Ceauşescu's autocratic rule during the 1980s Romanians had experienced extreme austerity (with almost all the population experiencing severe rationing of food and power) along with intrusive harassment and surveillance by the internal security services. Ceauşescu was overthrown and executed in the 'revolution' of December 1989 and the Romanian population was united in hoping for a better future. There was an almost unanimous condemnation of socialism among both the political elite and the wider public. Many of the leaders of the 1989 'revolution' were former members of the Romanian Communist Party with deep roots in the former regime. Thus they were eager to bury communism and avoid any questioning of their own pasts. ${ }^{53}$ It was perhaps for this reason that Romania was the only post-socialist state to formally ban the Communist Party. In addition, many Romanians were reluctant to confront their own complicity and co-operation with the former regime and preferred instead to forget. ${ }^{54}$ There followed a long period of amnesia in which the socialist past was erased from collective and individual memory: indeed, Romania was the exemplar of the authorized amnesia outlined above.

The 'official' repudiation of socialism culminated in the report commissioned by President Băsescu in April 2006 into the illegality and crimes committed by the socialist regime. This investigation was undertaken by a team of historians led by Vladimir Tismaneanu. The final report ${ }^{55}$ unequivocally condemned the socialist regime that had ruled between 1947-89. It was formally was accepted by the president who issued a public condemnation of the socialist era in a speech to the Romanian parliament in December 2006 (shortly before Romania's accession to the EU). However, the report was largely disregarded by the Romanian legislature. ${ }^{56}$

At the same time, nostalgia for the socialist era is pervasive among middle-aged and older Romanians. Various rounds of economic restructuring during the 1990s produced economic recession and a sharp decline in living standards. Neoliberal restructuring after 1996 increased the rate of closure of socialist-era industries and subsequent job losses. In addition, Romanians have looked on appalled as the socialist-era nomenclature have enriched themselves at the expense of the state. Unsurprisingly,

\footnotetext{
${ }^{51} \mathrm{~S}$. Legg, 'Sites of counter-memory: The refusal to forget and the nationalist struggle in Colonial Delhi', Historical Geography, 33 (2005), pp.180-201.

${ }^{52}$ Velikonja, 'Lost' p.547.

${ }^{53}$ T. Gallagher, Romania after Ceauşescu (Edinburgh: Edinburgh University Press, 2005),

${ }^{54}$ One of the authors recalls visiting Romania during the mid-1990s and attempting to engage various people in a discussion about the communist period. The response was invariably a polite but insistent refusal to talk about the subject.

${ }^{55}$ V.Tismaneanu (ed) Comisia Prezidenţiala pentru Analiza Dictaturii Comuniste din Romania: Raport Final, Accessed from www.presidency.ro on 1 March 2013.

${ }^{56}$ Stan 'Reckoning' p.137.
} 
there are many who feel that their lives were better during the socialist era, and opinion polls consistently confirm this. For example, in 1993, 13\% of the population reportedly approved of a return to communist rule. ${ }^{57}$ By $1998,51 \%$ of the population stated that life before 1989 was "better than now". ${ }^{58}$ By 2003 two-thirds of the population claimed to be nostalgic for communism. ${ }^{59}$ Indeed, many older people directly praise Nicolae Ceauşescu and speak of wanting to return to the order and certainty of the 1980s.

\section{Local Memories of Socialism}

Within this national context Romania, in common with other post-socialist states, exhibits a multitude of local memory formations which challenge official repudiation of the socialist past. Understanding memory in the post-socialist context also requires consideration of memory formation in different local and regional contexts, as memory is shaped by different histories and post-socialist trajectories, and rural and more peripheral contexts require consideration as much as the shaping of memory in the capital. In this section we explore a number of these local memories (in both rural and urban locations) in relation to key Romanian Communist leaders and politicians.

The first examples consider the local memories in remote rural areas of two significant former Romanian socialist politicians - Dr. Petru Groza and Emil Bodnăraș. Groza (1884-1958) was born in the small Transylvanian village of Băcia. He led the first, communist-dominated government after World War II, was Prime Minister (1945-52) and later titular Head of State (1952-58). After the War he played a key role in securing the return of northern Transylvania (which in 1940 had been annexed by Hungary) to Romania, an event which was organized by the Soviets to win him popular support. In the late 1940s he was instrumental in overseeing the Communist Party takeover of power and remaking post-War Romania as a socialist state following the model of the Soviet Union. He was also involved in enforcing the abdication of the King in 1947. His historical role in Romania's development is thus a complex one: although he was the prime minister of a socialist state he also remained a lay member of the Romanian Orthodox Church. After his death in 1958 he was buried in a Bucharest cemetery until 1965 when his body was moved to a monumental mausoleum constructed in a Bucharest park. In early 1990 his family moved his body from the mausoleum to his home village where he was reburied in the local churchyard.

Emil Bodnăraș was born in the small settlement of Iaslovăţ in the far north of Romania to a German mother and a Ukranian father. He had close links with the Soviet security services and worked as a Soviet spy in Romania. He was in charge of the internal security services during late 1940s when, with Soviet support, the Romanian Communist Party progressively took over the entire apparatus of state power. A committed communist and an army general he was Minister for Defence (1947-1955) and subsequently Minister for Transport and also held a number of other senior positions in the state apparatus. He is also credited with influencing Nikita Krushchev to withdraw Soviet troops from Romania in 1958.He showed total loyalty to Nicolae Ceauşescu when the latter rose to power in 1965. At his request he was buried not in Bucharest but in the village of his birth.

Both Dr Petru Groza and Emil Bodnaraş were closely associated with the Communist takeover of power and the transformation of the country into a totalitarian socialist state. Both were senior politicians in a state that ruled through repression and terror in the late 1940s and 1950s.

\footnotetext{
57 Ibid

${ }^{58}$ Radio Free Europe/Radio Liberty, 'Most Romanians believe life was better under Ceausescu', RFE/RL Newsline Vol.2, No. 229, Part II, 30 November 1998, http://www.rferl.org/content/article/1141792.html, accessed 14 February 2013.

59 Radio Free Europe/Radio Liberty, 'Poll shows Romanians inclined towards authoritarian leadership', RFE/RL Newsline Vol. 7, No. 199, Part II, 20 October 2003, http://www.rferl.org/content/article/1143025.html, accessed 14 February 2013.
} 
Unsurprisingly both are condemned in the 2006 Presidential Commission. ${ }^{60}$ Groza is described as an opportunist 'fellow traveller' who was exploited by the Romanian Communist Party to give a pretence of legitimate and representative government. Bodnaraş is portrayed as a shadowy power broker who was thoroughly implicated in the Communist Party's internecine internal conflicts. At the level of the Romanian state seeking to re-integrate itself into a regional European and global context they are repudiated figures from a rejected past. However, even at a national scale this state-led shaping of memory is differentiated, with, for example, several biographies and historical studies of Groza emphasizing other aspects of his achievements, such as his active involvement in the Romanian Orthodox Church. Both are recognized for their achievements (such as Groza's role in regaining northern Transylvania after the Second World War, and Bodnaraş's apparent involvement in securing the withdrawal of Soviet Troops from Romania).

However, it is when local memory formation around Groza and Bodnăraș is considered that the way that memory is formed in tension between the local, the national and the global is most explicit ${ }^{61}$. Despite condemnation by the post-socialist Romanian state, local memories of the two Communists are almost overwhelmingly positive. For example, the mayor of Băcia described Groza to be 'foarte apreciat' ('very much appreciated') by the majority of the local population in his home village. Similarly, Bodnăraș is admired for his patriotism: 'He was a patriot, he fought for the country, he was an officer. A good man.' Of course, it is a feature of these positive counter-memories that they are highly selective and involve as much forgetting as remembering. In neither case was mention made of any of the negative aspects of their actions or roles in Romania's development as a socialist state. In fact, the construction of their memories involves the exclusion of less favourable issues. In Groza's case people are keen to stress that he was not a Communist at all (despite being prime minister he was never a member of the Romanian Communist Party) while for Bodnăraș people emphasize that stories about his having been a Soviet spy and a murderer are wrong. Instead, both are held in high regard, as local 'men made good' who did much for the nation and for their places of birth. Their role in national affairs and their activities for the benefit of the nation (such as regaining Transylvania or 'resisting' Soviet control) are a particularly strong part of these positive counter-memories. In addition these local communities express a strong sense of ownership of both figures - they were 'ours' but went they went on to lead the nation. As one man in Băcia stated: 'he [Groza] left here and he led the country very well.' Both politicians are credited with having helped the church at a national and local level. Moreover, both are remembered for what they did to benefit their home villages while in power. As one woman commented about Bodnăraș "He was a good man. He did lots of things for the village - a school, church." In fact, such narratives often suggest that they would have done more in both cases but they were constrained by the Communist apparatus of which they were a part.

This de-linking of their characters and achievements from the Communist regime is a key aspect of the selective remembering which takes place. As a very elderly man in Iaslovăţ repeated several times "Bodnăraș was not such a passionate communist". In the case of Groza the emphasis is on his role as a national leader who was capable and developed the nation. As respondents in Băcia remembered 'He spoke personally to Stalin and convinced him to cede northern Transylvania to Romania' and 'He was the only man who opposed the Soviets.' In both cases these attributes are contrasted with presentday Romanian politicians. Thus these local memories are produced and reproduced in relation to the national in complex ways - simultaneously linking to notions of national pride but denying that accolade to post-socialist political parties and politicians, and reclaiming and maintaining positive memories of these local figures in a way running counter to state-led evaluations of their role during the socialist era. Indeed, in the case of Groza his memory is a source of contemporary pride which is used to distinguish the commune of Băcia and to build a sense of local identity. One respondent stated that 'He's a symbol of the commune' and the village's Mayor made the point that when people ask what Băcia is known for he is keen to stress the fact that it is the birthplace of Petru Groza.

\footnotetext{
${ }^{60}$ Tismaneanu, Comisia Prezidentiala, pp.647-8 \& 654.

${ }^{61}$ The quotes in the section that follows draw on field interviews with residents of Băcia and Iaslovăţ. While there were some dissenting or apathetic attitudes the local memories of these two figures are overwhelmingly positive
} 
These local counter-memories are also inter-twined with the fate of socialist-era statues in both Băcia and Iaslovăţ. After his death, Groza was commemorated through large statues in Bucharest and the Transylvanian city of Deva (where he had many associations). A smaller bust of the Prime Minister was erected in Băcia. One of the stereotypes of the end of socialist rule is the tearing down of statues as part of the 'de-Communisation' of the cultural landscape. However, the situation is more complex and these statues can have unexpected post-socialist trajectories. ${ }^{62}$ Certainly the statues of Groza in Bucharest and Deva were taken down and removed from public view (the Deva statue was abandoned at the back of the county hall in Deva). However, the bust of Groza in Băcia was not removed, although it suffered some minor vandalism. Unexpectedly the Deva statue was recently moved to Băcia at the request of the commune authorities who wish to re-erect it as a small tourist attraction intended to commemorate Groza's connections with his home village. ${ }^{63}$ Far from being despised symbols of the former regime, the statue and bust of Groza in Băcia are now material sites of countermemory, symbolizing the importance of local memories in shaping local identity in a way that runs counter to the efforts of the post-socialist state.

The situation in Iaslovăţ is even more unexpected. A bronze bust of Bodnaraş was erected in his home village after the politician's death and placed in front of the cultural centre (for which Bodnarass had arranged funding in the early 1970s). The bust was removed in early 1990s by local people during the period of elation that followed the overthrow of Nicolae Ceauşescu. However, local stories say little about it being removed as an unwanted communist symbol or as evidence of contempt for Bodnaraş. In 2003, on the initiative of the village authorities, a copy of the statue was produced and erected on the original pedestal where it still stands (see Figure 1). ${ }^{64}$ Again, it confounds the popular stereotype that the collapse of socialist regimes was accompanied by a purging of socialist symbols from the public landscape. The re-installation of the bust of Emil Bodnaraş testifies to sincerely-held local appreciation of him and it represents a significant manifestation of local memory that runs counter to the 'official' imperative to shape post-socialist memory by 'forgetting' socialism.

\section{Figure 1 somewhere after here}

\section{Caption: Figure 1: Bust of Emil Bodnaraş in Iaslovaţ, erected in the post-socialist period}

However, local memories of socialism are not confined to remote and rural parts of the country. Instead, counter-memories of socialism can also be found in the heart of Romania's capital, Bucharest. Again, we can illustrate this through the graves of socialist politicians, particularly the two General Secretaries of the Romanain Communist Party: Gheorghe Gheorghiu-Dej (1947-65) and Nicolae Ceauşescu (1965-89). Nicolae Ceauşescu was buried (initially under a false name) in Ghencea Cemetery in western Bucharest although the location and identity of the grave seem to have been well known. In the upheaval of the post-socialist period Ceauşescu's grave quickly became the focus for those nostalgic for the era of his rule. It is now a significant site of counter-memory in Bucharest. As early as 1992 the grave was being carefully maintained. ${ }^{65} \mathrm{~A}$ fence was erected around it and the original wooden cross replaced by a stone one (which features a red star). The grave is invariably covered with fresh flowers, candles and ribbons (see Figure 2), and it is not unusual to see individuals or groups assembled by it. During a visit to the grave one of the authors was told by a passing Romanian that "He [Ceauşescu] deserves something much bigger and nicer". It is the focal point for spontaneous and unorganized acts of remembrance by individuals who regret the passing of

\footnotetext{
${ }^{62}$ D.Light and C. Young, 'Socialist statuary as post-socialist hybrids: following the statues of Dr Petru Groza in Romania', Journal of Historical Geography, $37 / 4$ (2011), pp.493-501.

${ }^{63}$ Interview with the Primar (Mayor) of Băcia.

${ }^{64}$ Interview with the Primar (Mayor) of Iaslovăţ.

${ }^{65}$ D.A. Kideckel, 'The undead: Nicolae Ceauşescu and paternalist politics in Romanian society and culture', in J. Bornemann (ed) Death of the Father: An Anthropoligy of the End in Political Authority (New York: Berghahn, 2004), pp.123-147.
} 
Ceauşescu. It is also the site for more formal acts of commemoration on the anniversaries of Ceauşescu's birth and death. These are often organized by the successor to the Romanian Communist Party and are attended by small crowds (not all of whom are elderly).

Figure 2 somewhere after here

Caption: Figure 2: Nicolae Ceauşescu's grave in Bucharest

More surprisingly, the grave of Gheorghe Gheorghiu-Dej has also become a site of counter-memory, although to a lesser extent than that of Ceauşescu. Gheorghiu-Dej was a cynical and ruthless political operator who oversaw a period of state terror during the late 1940s and 1950s. On his death he was buried in the same mausoleum as Petru Groza and in the early 1990s his body was removed and reburied in a Bucharest. There are few with any reason to have fond memories of Gheorghiu-Dej's period of rule and yet even his grave has become a quiet site of counter-memory. Small groups of flowers can sometimes be seen on the grave and it is also the site for formal remembrance ceremonies (some of which are posted to Youtube). Both examples illustrate how local memories of socialism which contest the state-sponsored condemnation of Romania's socialist regime persist (and seemingly flourish) in the centre of the capital.

\section{CONCLUSIONS}

Tismaneanu talks about the "still unmastered past" ways the socialist era still haunts the present in this region. At the centre of this dilemma is the tension between remembering and forgetting. Post-socialist regimes have generally been eager to draw a line under state socialism and treat the socialist era as a historical aberration that is best forgotten. Moreover, the political imperative to demonstrate allegiance to multinational norms of political and economic development, along with national aspirations of a 'return to Europe', has demanded a repudiation of socialism in order to demonstrate adherence to 'Western' values. However, at the level of the individual, attitudes towards the socialist era are more ambivalent. For those who lived through the socialist era senses of personal identity are founded on, and grounded within, memories of that era. Socialism was the context within which people lived and worked, and which structured everyday lives. Many people are, therefore, reluctant to write off an entire period of their personal biographies. Add to this the sense of upheaval and disorder that has characterized the 'transition' to democracy and a market economy and it is unsurprising that many people feel nostalgic for the certainties of the socialist era. Looking back in this way is a strategy for dealing with the present.

This context creates circumstances where popular and local memories (or counter-memories) of socialism can collide with state-sponsored projects to repudiate the socialist era. In this chapter we have examined some examples of such local/counter memories in post-socialist Romania. The cases of Petru Groza and Emil Bodnaraş illustrate how socialist politicians who are condemned in official discourse can be held in high esteem in local contexts. Their role within the repressive apparatus of the socialist state (which is highlighted in official censure of their activities) is not denied, but other aspects of their lives and deeds are highlighted in more positive terms. In particular, both figures are venerated for their contribution to their home villages: it was their local activities and projects that had the greatest impact on the lives of people in those villages and it is these activities for which they are predominantly remembered. Lest such local counter-memories should be regarded as unique to isolated and peripheral parts of the country, the graves of Nicolae Ceauşescu and Gheorghe Gheorghiu-Dej also illustrate how popular counter-memories of socialism can flourish in the capital city. These examples illustrate the fluid, contextual and contested nature of memory in a post-socialist context. Of course, the experience in Romania cannot be generalized to every country of post-socialist East-Central Europe. The tension between remembering and forgetting is worked out in different

\footnotetext{
${ }^{66}$ Tismaneanu, 'Coming to terms', p.15.
} 
ways in each post-socialist country and will be influenced by circumstances such as the nature of the experience of socialism, the strength of civil society in the post-socialist era, and the will of the political elite to draw a line under state socialism.

Finally, a key point to emerge from this analysis is the need to consider the formation of memories of the socialist period which are more complex than outright condemnation or nostalgia. These two extremes have been the focus of most studies focusing on post-socialist memories to date. However, the case studies in this chapter have revealed the need for analyses which explore a more nuanced understanding of post-socialist memory that incorporates those two perspectives but also opens up the multiplicity of memories of the experience of socialism. Such memories might be condemnatory; nostalgic; about the everyday and the mundane (shortages, queuing, schooldays and holiday-making); about pride in achievement (both personal and national); and pride in the socialist nation and its national leaders. What the case studies in this chapter have shown is that the majority of memories are not clear-cut. The post-socialist Romanian state may have developed a strategy firmly based on the repudiation of the socialist past, but for the vast majority of Romanians their memories of the socialist era are much more nuanced and complex. Elites and publics are not monolithic entities and they have a vast range of personal and group experiences of socialism to draw on and a considerable diversity of social and political goals in the post-socialist context. Memories are formed at overlapping scales which bring the local, the national and the global into contact in complex ways. If contemporary memory is characterized by its democratisation (with the ability to form and promote different memories increasingly open to all) then in the post-socialist context it is vital to explore the perspectives of 'ordinary' citizens in those countries where political elites have repudiated the memory of socialism. Future studies of post-socialist memory formation need to let their voices and memories speak. 